\title{
Moldova - topos de legendă și nemurire
}

La Moldavie, topos de légende et d'immortalité

\section{Ramona Blajan}

\section{OpenEdition}

\section{Journals}

\section{Édition électronique}

URL : https://journals.openedition.org/cher/10035

DOI : $10.4000 /$ cher. 10035

ISSN : 2803-5992

\section{Éditeur}

Presses universitaires de Strasbourg

\section{Édition imprimée}

Date de publication : 1 décembre 2013

Pagination : 29-46

ISBN : 978-2-86820-560-5

ISSN : 1968-035X

\section{Référence électronique}

Ramona Blajan, « Moldova - topos de legendă și nemurire », reCHERches [En ligne], 11 | 2013, mis en ligne le 08 février 2022, consulté le 09 février 2022. URL : http://journals.openedition.org/cher/10035 ; DOI : https://doi.org/10.4000/cher.10035

\section{cc) (†)(2)}

Ce(tte) œuvre est mise à disposition selon les termes de la Licence Creative Commons Attribution Pas d'Utilisation Commerciale - Partage dans les Mêmes Conditions 4.0 International. 


\title{
Moldova - topos de legendă și nemurire La Moldavie, topos de légende et d'immortalité
}

\author{
Ramona BLAJAN \\ Université de Alba lulia - Roumanie
}

Despărțit de poporul meu prin exil, îl caut pe acesta fără contenire.

Constantin Virgil Gheorghiu și-a petrecut copilăria în ținutul Moldovei, comuna Războieni, satul Valea Albă, spațiu încărcat de puternice accente mitice după cum declară chiar el

M-am născut într-un sat pe versantul răsăritean al Carpaților, la 2000 de kilometri est de Paris, în nordul României, în provincia Moldova. Satul se numea Războieni. Nu m-am născut chiar în Razboieni, ci în unul din numeroasele sale cătune, care se numea Valea Albă. Județul în care se găsește comuna Războieni se numește Neamț ${ }^{1}$.

În opera sa autobiografică, și nu numai, scriitorul dezvăluie istoria acestui ținut, începând cu originile și continuând cu elementele care i-au marcat existența, și care au rămas mărturie peste veacuri. Apelativul dat locuitorilor, acela de «Nemuritori» - daci «barbari» renumiți pentru religia lor bazată pe jubilația în fața morții, sugerează eternitatea, urmările întâmplărilor la care au luat parte, regăsindu-se în denumirile localităţilor, în legăturile cu alte zone, și poate cel mai important în recunoașterea sacralității României, capabilă mereu să reînvie în ciuda propriului destin

1 C. V. Gheorghiu, Cum am vrut sa mă fac sfânt, Sibiu, Editura Deisis, 2008, p. 91. 
Strămoșii mei gândeau că adevărata lor patrie era cerul. Că nu se aflau pe pământ decât provizoriu. Moartea era pentru ei o întoarcere în patrie. Din această cauză, așteptau moartea, așa cum cei care călătoresc în străinătate așteaptă să se întoarcă acasă... ${ }^{2}$

Intreaga existență a acestei comunități, trebuie raportată la puternica comuniune cu cerul, cu Dumnezeu, în care au găsit refugiu în vremuri de restriște, așa cum mulți alții l-au găsit în codru.

C. V. Gheorghiu se prezintă în Memoriile sale, drept, "poetul lui Hristos și al României », iar dragostea de țară și strânsa legătură cu pământul natal, și-a exprimat-o de câte ori a avut posibilitatea, prin intermediul interviurilor acordate în exil, dar mai ales prin plasarea acțiunii din unele romane ale sale pe tărâm românesc. Scriitorul și-a dorit întoarcerea pe meleagurile natale, imediat după revoluția din 1989, însă starea de sănătate nu i-a permis acest lucru, trecând la cele veșnice cu acest mare regret. Deși condamnat de compatrioții săi din perioada de succes în ceea ce privește rapiditatea și calitatea operelor sale, C. V. Gheorghiu este scriitorul care a promovat viața, locurile, obiceiurile și legendele specifice României, prin intermediul unor romane din care răzbat dorul imens și dragostea fierbinte față de țara natală, după cum remarca și eseistul George Alexe

Întreaga operă literară a Părintelui Constantin Virgil Gheorghiu din Paris, Franța, purcede din dragostea sa fierbinte față de poporul românesc. Continuând tradiția marilor scriitori-sacerdoți din România, el îmbogățește cu fiecare nou roman din literatura universală, descoperind lumii întregi adâncurile de taină ale vieții și spiritualității românești. Este marele său merit de a fi aflat în creștinismul popular românesc pârghia de rezistență morală a Neamului nostru, față de grelele asupriri și încercări prin care a trecut în decursul istoriei sale bimilenare. Drept aceea, Părintelui Constantin Virgil Gheorghiu i se poate spune, pe bună dreptate, apologet modern al Creștinismului românesc. ${ }^{3}$

Spațiul de suflet al scriitorului, așa cum se poate remarca și din biografia acestuia, este fără îndoială, Moldova, țară a vârstei de aur, a cărei emblemă o constituie bourul alb din singuratățile munților, topos sacralizat prin vechime, aflat sub lumina soarelui în asfințit.

Patosul patriotic al scriitorului este evident prin tetralogia românească constituită din Casa de la Petrodava (1961), Nemuritorii de la Agapia

2 C. V. Gheorghiu, Memorii. Martorul Orei 25, București, Editura Gramar, 2003, p. 23.

3 George Alexe apud Fănuș Băileșteanu, Nihil Sine Deo sau Cruciada literară a ecumenistului Constantin Virgil Gheorghiu, Craiova, Editura Autograf, 2005, p. 147-148. 
(1964), Le meurtre de Kyralessa (1966) și La condottiera (1967). Fiecare dintre acestea are ca topos un tărâm fabulos, încărcat de taine, legende și frumuseți tulburătoare, fie că se numește Petrodava, Agapia, Kyralessa sau Acatist, toate făcând însă trimiteri, la locurile copilăriei sale și constituinduse totodată «într-un avatar al satului natal al scriitorului»".

În toate cele patru cărți se simte mereu o existență pe doua tărâmuri: real și fantastic, o atmosferă miraculoasă și legendară în care se proiectează o lume vitează, măreață, care dezvăluie tainele naturii și ale oamenilor. O spiritualitate autohtonă trăiește în preajma pădurii, muntelui, cu practici primitive, iar istoria este proiectata în fantastic și monumental. Eroii sunt oameni cu o anumită structură sufletească, oameni blajini și înțelepți, cu un acut simț al dreptății, al libertății și demnității, apărători ai unor principii etice fundamentale. Răbdători în suferință, țin veșnic în sufletul lor dureri nestinse și se retrag în mijlocul naturii, fugind de forțe ostile, fie răbufnesc cu violență împlinindu-şi dreptatea și menținând nealterat sentimentul demnității umane.

Preocuparea pentru originile și evoluția poporului său, văzut ca popor al nemuritorilor, a cărui legendă este evocată în operele amintite mai sus, se remarcă încă din anul 1955, când îi apare opera Le peuple des immortels. După cum mărturisea chiar autorul, intenția sa, a fost, ca prin intermediul acesteia, să reînvie interesul pentru trecutul țării sale, și, totodată, să dezvăluie caracterul României, și al locuitorilor acesteia, în urma amestecului de civilizații desfășurate de-a lungul vremii

Je cherche ma patrie avec la même insistence que la lumière, l'eau et l'air, et puisque je ne la retrouve plus, je reconstitue pour moi ma patrie, afin de l'avoir ici - avec moi - parce qu'elle est nécessaire à ma vie. ${ }^{5}$

Cartea nu este un roman, este mai degrabă o operă cu caracter istoric, în care autorul folosește, deosebindu-se astfel de istoric, pasiunea unui descendent, talentul artistic și tehnica detaliului, pentru a reconstitui istoria, portretul, neamului său, redând trăirile, motivările și gesturile strămoșilor săi: dacii. Determinarea scriitorului vine din legătura puternică pe care o are cu strămoșii săi și învățăturile acestora, ce l-au însoțit pe tot parcursul

4 Thierry Gillyboeuf, Rapsodia română, prefață la romanul Casa de la Petrodava, București, Editura Sophia, 2010, p. 11.

5 C.V. Gheorghiu, Le peuple des immortels, Paris, Editura Plon, 1955, p. 106: «Îmi caut patria cu aceeași insistență ca lumina, apa, aerul, și până nu o regăsesc, eu reconstitui pentru mine patria mea, pentru a o avea aici - cu mine - pentru că ea este necesară vieții mele» (traducerea noastră). 
vieții chiar și pe un alt tărâm «Tout ce qui compose la vie de mon peuple fait partie de ma vie. Tout ce qui fait partie de l'Histoire des Daces est partie intégrante de ma personne». ${ }^{6}$

Asemenea unui vizionar, C. V. Gheorghiu reînvie perioadele arhaice în care Romanii și Sciții au intrat în contact cu regiunea căreia îi corespunde astăzi România; aici în «le pays rond du Danube», strămoșii noștri, ai românilor, au rezistat mult timp la toate tentativele de cucerire sau anexare. Scriitorul relatează istoria acestui popor care pare a fi atins un anumit grad de civilație: popor războinic dar care nu masacra niciodată prizonierii, popor «juste et intelligent», după spusele vechilor istorici, uniți întotdeauna în jurul regilor lor, aleși din rândul înțelepților, și, în fine, popor religios, crezând în imortalitatea sufletului încă dinainte de creștinism. Numiți din acest motiv "popor al nemuritorilor», Dacii au fost în final învinși și colonizați de către Romani, dar doctrinele lor religioase datorate lui Zamolxis, șeful lor spiritual, se vor menține intacte până când sclavii creștini trimiși de Roma în minele Daciei, au introdus creștinismul, confirmându-le astfel nemurirea. Subliniind analogiile dintre Daci și Romani, C. V. Gheorghiu remarcă «Nos ancêtres luttèrent toute leur vie pour ne pas perdre l'éternité».7

Viaţa în exil l-a determinat să retrăiască istoria și evenimentele din patria sa, să le caute, simțindu-se astfel mai aproape de pământul părăsit și reîntregindu-se doar prin evocarea acestuia și nu prin comuniune, care nu a mai fost din păcate posibilă

Un homme qui vit en exil et un homme qui a perdu son peuple, comme j'ai perdu le mien. Son propre peuple est pour un homme le prolongement de sa chair et de son être. Perdre son peuple équivaut, par exemple, à perdre ses yeux, ses bras, sa raison ou son ombre. Cette perte une fois consomée, il devient impossible de vivre avec dignité. Et parce que moi - je ne puis vivre sans dignité, je cherche désespérément mon peuple. ${ }^{8}$

Și este evident că a făcut-o prin cărțile sale.

Romanul «cel mai românesc» al lui C.V. Gheorghiu este fără îndoială Casa de la Petrodava, apărută în Franța în $1961 \mathrm{cu}$ titlul La maison de

6 Ibidem, p. 107.

7 Ibidem.

8 Ibidem, p. 10: «Un om care trăiește în exil este un om care și-a pierdut poporul său, așa cum şi eu l-am pierdut pe al meu. Propriul popor este pentru un om o prelungire a trupului și al ființei sale. A-și pierde poporul echivalează, de exemplu, cu pierderea ochilor, a brațelor, a rațiunii sau a umbrei sale. Această pierdere odată consumată, îi devine imposibil să trăiască cu demnitate. Și pentru că eu nu pot trăi fără demnitate, îmi caut cu disperare poporul meu »(traducerea noastră). 
Petrodava și reeditată apoi, după moartea scriitorului, sub titlul de Les noirs Chevaux des Carpates. Pe lângă elementele mitice specifice zonei evocate în carte, apar și elemente reale, C. V. Gheorghiu realizând după cum însuși mărturisește o descriere autentică a ținutului natal «Casa de la Petrodava nu este o operă de ficțiune pură, ci - mai degrabă - o cronică a lumii din care vin $» .^{9}$ Romanul impresionează aşadar, nu numai prin subiectul abordat, sau prin rădăcinile personale și colective care îl scot dintr-o uitare mai mult sau mai puțin justificată, ci mai degrabă prin maniera prin care trensformă o cronică într-un roman, și un roman în epopee.

Petrodava, satul în care este plasată acțiunea romanului amintit mai sus, este vechiul nume geto-dac, al orașului Piatra Neamț, ținutul natal al scriitorului cercetării noastre și se găsește în Valea Bistriței, pe versantul oriental al Carpaților

România are forma unui disc. Mai exact, ca această farfurie. Aici trăiesc douăzeci de milioane de oameni. Pe marginile farfuriei se află câmpiile. În centru, pe fundul farfuriei, este podișul carpatic. Seamănă cu o citadelă. În această citadelă naturală a munților se află satul meu, Petrodava. E un nume dacic. Sunt mii de ani e când aici, unde se află acum România, trăia un popor care s-a numit poporul dac. ${ }^{10}$

Imediat după redarea coordonatelor reale ale regiunii, C.V. Gheorghiu ne transpune în lumea legendei, urmărind să scoată în evidență calitatea umană a celor care conviețuiesc pe aceste meleaguri, și anume eternitatea prezenței pe aceste meleaguri printr-o viață continuată după moartea terestră, în cer, și păstrarea cu sfințenie a valorilor morale și fizice ale strămoșilor, calitate pietrificată parcă în inima acestui popor, numit atât de expresiv de scriitor - «popor al nemuritorilor» - și evocat în operele sale fie prin inserarea unor momente istorice legate de evoluția acestuia fie ca titlu de operă „Acești daci își dăduseră ei înșiși numele de "poporul nemuritorilor », pentru că ei credeau că nu vor muri vreodată. Considerau moartea ca pe o simplă mutare de pe pământ la cer. Schimbarea unei locuințe sărace cu una mai bună. Toți acești daci ori nemuritori se grăbeau să moară pentru a se muta în locașurile cerești, care după spusele zeului lor, Zamolxis, erau pline de splendoare. Cea mai bună cale de a muri, atunci, ca și acum, era războiul. Poporul nemuritorilor se arăta nespus de fericit de fiecare dată când izbucnea un război. O ocazie pentru a muri. Romanii, care în vremea lor au fost cei mai

9 C. V. Gheorghiu, motto la romanul Casa de la Petrodava, București, Editura Sophia, 2010.

10 Idem, p. 144. 
mari distrugători de națiuni ai universului, au pus la cale un război pentru a distruge poporul nemuritorilor. Lupta a durat trei sute de ani. Victoria a fost mereu de partea nemuritorilor, care au rămas independenți până în secolul al II-lea după Hristos. Atunci au avut neșansa de a pierde războiul. Romanii au pătruns în citadela munților, a acestui fund de farfurie. Pentru ca spada să nu-i cadă în mâinile dușmane, Decebal, regele dacilor, a frânt-o în două. $\mathrm{Cu}$ o parte din sabia sa și-a luat singur viața, înfingându-și-o în inimă. Pentru că nu voia să cadă viu în mâinile dușmanilor săi. Toți generalii s-au sinucis, unul după altul, după înălțimea rangului. S-au omorât cu spadele lor sfărâmate, în apropierea trupului regelui lor. Totuși ca să se încheie aceasta cât mai repede, bărbații, de la cel mai tânăr până la cel mai în vârstă, au umplut un cazan cu otravă, din care au băut fiecare câte o cupă. Au căzut morți. Astfel au murit bărbații din poporul nemuritorilor. Femeile au vrut să sfârșească și ele, pentru că viața sub ocupație străină nu mai avea sens. Insă, înainte de moartea sa, regele a spus că femeile nu aveau dreptul să se sinucidă, căci ele aveau roada părintelui lor, copiii, care trebuiau crescuți. Astfel la Petrodava, care în limba greacă înseamnă Cetatea de Piatră, nu au mai rămas decât femeile nemuritorilor. După o vreme, romanii au ajuns și aici. Apoi Dacia a fost invadată de către barbari. După moartea soților lor, femeile au rămas să trăiască în Carpați cu roada pântecelui lor. În munți, fără să se teamă de moarte. Rămase pe pământ doar pentru a-și îndeplini misiunea lor de femeie." 11

Pornind de la ultima parte a legendei legată de istoria ținutului Petrodava, C. V. Gheorghiu alege ca protagoniste pentru romanul Casa de la Petrodava personaje feminine. Fiind așadar singurele ființe rămase să ducă mai departe prestigiul poporului nemuritorilor, acestea dobândesc în opera amintită calități și puteri extraordinare. În ținutul legendar, Petrodava, se remarcă neamul Roca, o dinastie de crescători de cai renumiți în toată România și țările vecine. După trei ani de așteptare, învățătorul Lucian Apostol obține în sfârșit mâna unicei fiice a familiei Roca, Roxana. Foarte încântat, îi jură credință veșnică, cu toate că ar fi trebuit să aibă o reținere deoarece s-a legat de o persoană de la munte, dură ca și rocile sale, violentă ca și torentele apelor de munte. Exigentă, verticală în intransigențele sale, Roxana îl lasă să moară în zăpadă, în fața porții, pe soțul său despre care află că o înșela. Fiica lor, Stela, este o demnă moștenitoare a mamei sale. O demonstrează luptând pentru salvarea primului său soț, un prinț rus, însă ea împinge până la absurd sensul dreptății. Cel de-al doilea soț, un locotenent retras din

11 Ibidem, p. 144-145. 
armată în urma unei boli dobândite în tranșee, și rămas cu sechele din cauza terorilor la care fusese martor în război, nu este capabil să-i ofere tandrețea de care are nevoie o femeie de la munte, și totodată pasiunea pentru viața dură din munți, iar la nici doi ani de la căsătorie, drama izbucnește, brutală și pasionantă pe măsura personajelor.

Pe parcursul relatării evenimentelor, C.V. Gheorghiu nu scapă nici un moment ocazia de a reda aspecte referitoare la organizarea gospodăriilor din această zonă, despre oamenii care o populează și comuniunea acestora cu locurile care îi înconjoară. $\mathrm{Nu}$ lipsesc obiceiurile și credințele populare care transformă ținutul prezentat de scriitor în unul puternic ghidat de mitologia locală. Astfel că

La Petrodava, casele, curțile, acoperișurile sunt construite din lemn și trăiesc atât cât trăiește omul. Petrodava e ca natura. Ca o grădină. Casele de la Petrodava trăiesc anotimpurile vieții omenești. Casele mor în același timp cu cei care le-au zidit și renasc - în același loc, reînnoite - pentru cei care urmează. Diferite, adaptându-se tinerilor lor locuitori. Dacă vreți să ştiți vârsta unui om din Petrodava, e nevoie să priviți doar casa în care locuiește. E un fel de portret al proprietarului. Dacă vedeți zidurile care formează spatele gros, acoperișul care se apleacă, veți spune că proprietarul este la fel - cu spatele îndoit, cu căciula de blană pe ochi, căutând un sprijin.Însă cele mai multe case sunt vesele, pentru că sunt tinere. Râd cu toate ferestrele sale deschise către cer, cu toți pereții lor albi. S-ar putea spune că sunt tinere căsătorite. Acoperișurile lor de șindrilă cenușie argintată sunt ascuțite ca vârfurile brazilor ori cușmele tinerilor lor stăpâni. ${ }^{12}$

Deși este o zonă muntoasă, locuitorii nu folosesc piatra drept material de construcție a caselor sau crucilor, ci lemnul, conștienți fiind că viața pe pământ nu durează o veșnicie, neîncercând să forțeze astfel destinul, deoarece succesiunea generațiilor este respectată aici, cei tineri iau locul celor bătrâni, mormintele tinere iau locul celor vechi, lucru acceptat atât de ușor datorită credinței din strămoși că moartea înseamnă doar strămutare a vieții, în cer

La Petrodava piatra este minunată; o afli peste tot. Însă piatra nu este «maleabilă», nu se supune anotimpurilor vieții omenești. Piatra face ca un mormânt ori o casă să dureze mai mult decât este firesc. Ceea ce durează mai multă vreme devine muzeu ori închisoare. Ajunge o povară. Un obstacol. Împiedică să se dezvolte o viață nouă. ${ }^{13}$

12 Ibidem, p. 160.

13 Ibidem, p. 161. 
Faptul că ținutul Petrodavei, reușește să fie un păstrător al tradițiilor, al legendelor și obiceiurilor transmise de strămoșii lor, nemuritorii, se datorează în primul rând valorii umane a oamenilor care își duc viața pe aceste meleaguri, oameni verticali în deciziile lor, demni și cumpătați în același timp

Noi, muntenii, care trăim agățați de creste, deasupra prăpăstiilor, noi ținem seama de fiecare pas pe care trebuie să-l facem, pentru că ne angajăm viața noastră odată cu acesta. Pentru un om de la Petrodava, un pas poate fi chiar ultimul, dacă nu s-a gândit bine ce face. ${ }^{14}$

Fiind considerată zona cea mai apropiată de cer, oamenii din ținutul Petrodavei se simt datori să se ridice la înălțimea munților, ducând o viață exemplară ghidată după principii și credințe străvechi

Petrodava este «o culme» la propriu și la figurat. Geografic este mai aproape de cer decât de pământ, pentru că se află foarte sus, la altitudine, în Carpați. ${ }^{15}$

Aceeași idee a comuniunii omului cu cerul este prezentă și în cazul descrierii orașului Agapia, situat

la trei mii de kilometri de Paris, în marea mahala a Europei, pe versantul de est al Carpaților, acolo unde-ncepe marea câmpie, stepa care străbate Rusia și se pierde în fundul Asiei"16

și totodată locul acțiunii din romanul Nemuritorii de la Agapia

geografic ne aflăm mai aproape de cer decât de pământ. Bună parte din an ne găsim deasupra norilor care trec totdeauna mai jos decât orașul Agapia. ${ }^{17}$

Fiind o localitate situată la înălțime, locuitorii acesteia sunt conștienți de privilegiul de care au parte și și-au modelat viețile după cerințele zonei

aici totul se petrce astfel decât în alte părți. Este un oraș desprins de pământ, la propriu și la figurat. Iar oamenii din acest oraș sunt mai degrabă cetățeni ai cerului decât ai pământului. ${ }^{18}$

Numele orașului este în concordanță cu atmosfera de liniște, calm, iubire și conviețuire liniștită în care trăiesc cetățenii acestuia

Noi, aici, la Agapia, suntem creștini [...] Și numele orașului - Agapia - și numele străzii principale sunt religioase. Agapé înseamnă dragoste. Orașul nostru este un oraș curat. Un oraș serios, fiindcă e creștin. Oamenii de aici

14 Ibidem, p. 177.

15 Ibidem, p. 204.

16 C. V. Gheorghiu, Nemuritorii de la Agapia, București, Editura Gramar, 1998, p. 5.

17 Ibidem, p. 70.

18 Ibidem, p. 71. 
sunt tare amărâți. N-au avut noroc în istorie. Dar toată lumea e curată. Să fii curat înseamnă mai țntâi să nu îngădui petele. Nici o pată. Iar pata de sânge e cea mai murdară dintre toate. ${ }^{19}$

Spațiul descris este un loc în care "nu se întâmplă nimic», dar în care se petrec, la nivel individual, ratări, drame, iluzii sfărâmate. Admirația și dragostea față de acest popor și respectul pentru faptele și valorile moștenite de la strămoși a lui C.V. Gheorghiu răzbate și din acest roman, acesta subliniind prin deja obișnuita legendă a "poporului nemuritorilor $»^{20}$, suferințele la care au fost supuși locuitorii acestei zone și totodată rezistența, venită în cea mai mare parte de la Dumnezeu, cu ajutorul căruia au trecut peste toate și mai ales prin comuniunea cu cerul care le-a asigurat refugiul și nemurirea în vremuri grele «La noi cerul a înlocuit pământul. Cerul era ogorul nostru, grădina noastră, așezarea noastră, turma noastră ».21

După cum ne-a obișnuit, C.V. Gheorghiu alternează pasajele descriptive puternic miticizate cu cele reale

Agapia, este ca un port; munții coboară până la calea ferată, pentru a-ntâlni câmpia. Ca și când ar întâlni marea. Căci regiunea de la răsărit de calea ferată se deosebește de cea de la apus, cum se deosebește marea de uscat. La răsărit pământul e negru, bogat, roditor, neted. La apus, munții sunt ca un zid, cu pământ pietros și dur. La răsărit, vara este praf, sunt țânțari. La apus, pe Drumul Iubitoarelor nu e niciodată praf. Vântul mătură totul și spulberă praful spre câmpie. Din când în când, trec nori, împinși de vânt și, asemeni unor imenși bureți umezi, spală pietrele, casele, aerul. De o parte și de alta, oamenii se deosebesc între ei ca și cele două regiuni. La răsărit de calea ferată, în câmpia fertilă, murdară, noroioasă și bogată, oamenii sunt bondoci, îndesați, rotunzi la obraz; le plac banii și viața și le râd ochii. La apus, în casele care mărginesc Drumul Iubitoarelor, bărbații și femeile sunt înalți, slabi, aproape uscați și cu priviri severe. Pun prea puțin preț pe viața pământească și pe plăcerile trupești. Visează la o împărăție mai bună. ${ }^{22}$

Este evident însă că scriitorul, fie că descrie un tărâm fabulos fie că ne transpune în realitate, păstrează totuși aceeași linie a evocării unei lumi perfecte, cu oameni drepți, creștini, iubitori, demni și totodată păstrători ai unei încrederi de neclintit în tradițiile și valorile transmise de strămoși, a căror suferință și durere, atât fizică cât și interioară, trebuie răsplătită pe deplin.

19 Ibidem, p. 67.

20 Ibidem, p. 78, Legenda nu este citată de noi deoarece este în mare parte asemănătoare cu cea prezentă în romanul analizat anterior Casa de la Petrodava

21 Ibidem, p. 79.

22 Ibidem, p. 91. 
Pe fundalul unei descrieri făcute de comisarul Filaret noului judecător Cosma Damian, care prezintă orașul Agapia ca fiind unul «curat» prin aceasta înțelegându-se „județ fără cazier judiciar » și fără nici o altă problemă de natură judiciară «Din străvechi timpuri și-n mod sigur de când există lumea, nimeni n-a comis la noi omor, viol, vreo crimă »23, la nici douăzeci și patru de ore de la instalare, i se raportează o crimă. Este vorba de Anton Tuniade, fiul castelanei Patricia Tuniade, o familie de satrapi fanarioți. Incepe o anchetă minuțioasă, prin investigații la locul crimei, interogări de martori și presărată pe alocuri cu elemente de natură să spulbere anumite reguli judiciare, și conducă ancheta pe un drum al analizei faptelor din perspectiva asocierii oamenilor cu caracteristicile locului și a legendelor care îl caracterizează. Astfel, moartea tatălui lui Anton Tuniade, ucis Sava Mold cu o secure în cap, închis acum la ocnă, este văzută mai degrabă ca o sinucidere de către comisarul Filaret, deoarece era un om foarte rău și obișnuia să le ia oamenilor bunul lor cel mai de preț: securea. Pentru oamenii din această zonă lemnul era singura sursă de existență, iar securea instrumentul care le-o asigura, și pe care Tuniade-tatăl i-o confiscase cu cruzime lui Sava, elemente care îi permit comisarului și oamenilor din zonă, puternic influențați de credința populară și păstrarea valorilor străbune, să claseze crima drept o moarte cerută prin opunerea la substratul convingerilor care guvernează populația orașului Agapia, și moldovenii în general, nevoiți să suporte asuprirea fanarioților

Moldovenii nu sunt inferiori altor nații de pe pământ. Dar au îndurat și-ndură o nenorocire neîncetată, de la apariția lor pe pământ. De secole, satrapii, organizați în bande politice, în partide, au pătruns în trupul poporului moldovean, ca viermii paraziți, și-l devoră dinăuntru și din afară. ${ }^{24}$

Judecătorul, nefiind un cunoscător și totodată un încrezător al locurilor și legendelor specifice acestuia, îl consideră vinovat pentru moartea lui Anton Tuniade, tot pe Sava Mold, ucigașul tatălui său, considerând crima o răzbunare. Ca o coincidență, Sava tocmai evadase de la ocnă, iar în urma torturilor și îndeplinirii dorinței de a-și vedeași mângâia copiii, lucru pentru care și evadase de fapt, mărturisește o crimă pe care nu a comis-o. De fapt crima fusese comisă de amantul doamnei Tuniade, care deși își mărturisește crima, nu este pedepsit deoarece există deja un acuzat, Sava Mold, care moare în drum spre ocnă.

23 Ibidem, p. 9.

24 Ibidem, p. 102. 
Deși un roman cu tentă polițistă, scopul acestuia nu este neaparat de aflare a adevărului, și arestarea adevăratului criminal, ci mai degrabă de evidențiere a laturii sociale a oamenilor și în special a zonei în care se petrece crima. Nedreptățile sociale și politice la care au fost supuși, sarcasmul împotriva satrapilor, fanarioților care și-au urmărit doar interesele explică motivul stării de spirit a scriitorului care-și face simțită «sensibilitatea românească » prin compasiunea față de cei care au rezistat în fața cotropitorilor străini, care au încercat să batjocorească credința și demnitatea etnică. Arma principală a acestora, a fost fără îndoială, moștenirea de la strămoși, «poporul nemuritorilor», care le-a întărit credința în nemurire și mai ales în viaţa minunată ce-i așteaptă pe celălat tărâm, în cer.

Sub auspiciul legendei și nemuririi este plasată și acțiunea romanului Le meurtre de Kyralessa, apărut în Franța în 1966 și netradus încă în limba română. Păstrând linia anchetelor polițiste, din romanul anterior, C.V.Gheorghiu imaginează de această dată un personaj legendar, Bogomil, țesând apoi în jurul capturării acestuia, acțiunea, care scoate în evidență conduita eroilor săi, guvernată întotdeauna de înțelepciunea populară. Eposul popular realizat de scriitor în operele amintite mai sus pendulează între legendă, istorie, mit și spirit baladesc.

Ca și în cazul celorlalte romane, în care titlul conține numele locului în care se desfășoară acțiunea, Le meurtre de Kyralessa, dezvăluie încă de la primul contact cu cartea, un alt loc și totodată un personaj legendar. Kyralessa este numele unui om și al unui sat, primul fiind originea celui de-al doilea, și care se găsește localizat în vârful unui munte din Carpaţi, în Moldova, permițându-le astfel locuitorilor de aici privilegiul unei atente supravegheri atât din partea lui Dumnezeu cât și a strămoșilor și totodată asigurându-le o continuitate și o adâncire în ireal

Ici, dans ces montagnes, l'homme et sa vie se veulent à la mesure de Dieu; c'est pourquoi ils quittent la réalité, la terre, la mesure raisonnable. Au pays des Carpathes, tout chose se prolonge dans l'irréel, dans le supraterrestre, dans la légende, dans le mythe. ${ }^{25}$

Caporalul Kyralessa deși are statuia sa în piața satului, deoarece a murit ca erou în timpul războiului, nu el este cel venerat de către concetățenii săi, ci tâlharul Bogomil, considerat ca înzestrat cu puteri supranaturale, de care

25 C.V. Gheorghiu, Le meurtre de Kyralessa, Paris, Editura Plon, 1970, p. 29: "Aici în acești munți, omul și viața sa sunt menite lui Dumnezeu; de aceea ei părăsesc realitatea, pământul, măsura rezonabilă. În țara Carpaților fiecare lucru se extinde în ireal, în supraterestru, în legendă, în mit» (traducerea noastră). 
se folosește pentru a-i despuia pe tiranii fanarioți, ce îi asupresc de secole întregi. Este ceea ce i se spune și generalului Dracopol, despot al Kyralessei, însărcinat cu prinderea lui Bogomil, și care îl determină să izbucnească în râs. Aceste puteri se explică în ochii lui prin complicitatea sătenilor, propunându-și să-i aresteze pe toți pentru a-i constrânge să îl trădeze pe Bogomil. Cu toate eforturile depuse, cu toate pedepsele și bătăile aplicate sătenilor, aceștia nu-i oferă decât informații care îl plasează pe acesta în ireal, pe un tărâm fabulos care îi permite să se deplaseze și să facă tot ceea ce-și dorește fără a fi prins. Bogomil nu este altul decât caporalul Kyralessa, care împușcat de către generalul Dracopol într-o noapte când era beat, și considerat mort, este aruncat de sclavul acestuia Haralamp Halipan pe teritoriile de război nemțești. Nemții îl găsesc încă în viață, și îl tratează timp de doi ani, punându-l pe picioare. Întorcându-se acasă își vede nevasta, cu un alt bărbat, iar pe lângă copilul său încă unul, și se retrage în pădure, de unde iese doar pentru a jefui diligențele de poștă care transportau banii pentru tezaurul național. Fiecărei fapte a lui Bogomil finalizată fără a fi descoperit, fiecărei calități, utilizate în demersurile sale, i se atribuie o legendă; astfel deschiderea seifului cu bani și aur fără a rupe sau tăia lacătul, i se datorează posesiei, în viziunea populară a «florii metalelor » care poate deschide orice ușă sau orice lacăt

Bogomil possède dans la paume de sa main droite, «La fleur des métaux» [...] C'est une toute petite fleur. Bleue comme le myosotis, mais beaucoup plus petite, plus fine et plus belle. Si on en trouve un seul brin et si on fait dans la paume de sa main droite, avec un couteau, une entaille profonde, si on y met la Fleur de métaux, dans la chair, près de l'os, quand la plaie est guérie on peut ouvrir, rien qu'en touchant de la main, n'importe quelle serrure. ${ }^{26}$

Pe lângă această înzestrare, care îi permite să nu lase urme la locul faptei, Bogomil se și deplasează fără a fi văzut

...il peut marcher sans faire du bruit et sans laisser de traces. [...] Il peut se cacher en se collant à la terre jusqu'à ne faire plus qu'un avec elle - jusqu'à devenir pareil à la terre. (...) les soldats peuvent marcher sur lui sans le savoir. Il entre dans un puits et il y reste, la tête sous l'eau des heures entières.

26 Ibidem, p. 33: «Bogomil are în palma mâinii drepte Floarea metalelor [...] Este o floare foarte mică. Albastră ca și floarea de nu-mă-uita, dar mult mai mică, mai gingașă și mai frumoasă. Dacă găsești un singur fir, și faci în palma mâinii drepte o tăietură adâncă, în care pui Floarea metalelor, în carne, aproape de os, atunci când rana va fi vindecată poți deschide, doar atingând cu mâna, orice închizătoare» (traducerea noastră). 
Il a des poumons si forts qu'il n'as pas besoin de respirer, comme nous, à chaque instant. ${ }^{27}$

sau poate auzi mesajele și plângerile semenilor săi fără a se întâlni față în față cu ei, ci doar folosindu-se de pământ și vânt

Tout le monde sait, [...], comment il faut appeller Bogomil. On colle la joue droite contre la terre. On appelle et on raconte à Bogomil, la bouche sur la terre, son malheur et l'injustice subie. Et la terre transmet le message à Bogomil. Il l'entend, le soir, en collant l'oreille à la terre moldave, comme au téléphone. Il entend chaque soir des centaines et des centaines d'appels. Il ne se couche jamais sans écouter ce que lui transmet la terre. La nuit, il dort l'oreille collée contre la terre, pour entendre les plaintes des gens. Si l'on ne peut pas parler à la terre, on sort, on se plante sur le seuil de la maison et on parle au vent. Et le vente porte la plainte et la requête à Bogomil.28

Toate aceste calități ale lui Bogomil se dovedesc a fi în final doar simple coincidențe, după cum mărturisește chiar el, atunci când este nevoit să-și facă apariția pentru a avea grijă de fiul său, rămas singur pe lume, după moartea surorii și mamei lui. Îl șantajează pe generalul Dracopol cu dezvăluirea adevărului despre crima comisă asupra caporalului Kyralessa, actualmente Bogomil, și obține eliberarea învățătorului care îl pregătise pe fiul său pentru examenul la liceu și care trebuia să-l însoțească.

Nevoit să suporte de-a lungul vremii nenumărate asupriri și nedreptăți, poporul moldovean, a reușit să reziste, în viziunea lui C. V. Gheorghiu, prin ancorarea în trecut - ținând mereu seama de moștenirea primită de la strămoșii lor, "poporul nemuritorilor » ${ }^{29}$, în ireal, prin crearea de legende, care i-a îndepărtat de realitate, ca printr-un zid, deoarece orice le-ar fi putut confisca asupritorii, numai spiritul și simbolurile specifice zonei nu.

27 Ibidem, p. 47: «...el poate merge fără să facă zgomot și fără să lase urme. Se poate ascunde lipindu-se de pământ până se face una cu el, devenind la fel. Soldaţii pot trece peste el, fără să știe. Intră în fântâni și poate sta cu capul în apă ore întregi. Are plămâni atât de puternici încât nu are nevoie să respire ca noi, în fiecare minut» (traducerea noastră).

28 Ibidem, p. 78-79: «Toată lumea știe, cum trebuie să-l chemi pe Bogomil. Lipești obrazul drept de pământ. îl strigi și îi povestești lui Bogomil, cu gura spre pământ, nefericirea și nedreptatea îndurată. Și pământul transmite mesajul lui Bogomil. El îl aude, seara, lipind urechea de pământul moldovenesc, ca la telefon. El ascultă în fiecare seară sute și sute de apeluri. Nu se culcă niciodată fără să asculte ceea ce îi trensmite pământul. Noaptea el doarme cu urechea lipită de pământ, pentru a auzi plângerile oamenilor. Dacă nu se poate vorbi pământului, ieși, te așezi pe pragul casei și vorbești vântului. Iar vântul poartă plângerea și cererea la Bogomil» (traducerea noastră).

29 Ibidem, p. 316-317: «Informații legate de existența în strânsă legătură cu cerul și Dumnezeu, a poporului nemuritorilor, sunt redate și în acest roman, sub forma unei legende care întărește comuniunea acestui popor cu cerul și cu nemurirea». 
Moldovenii și-au apărat cu orice preț legendele, singurele care le-au dat lumina - adică dreptatea, adevărul, frumusețea, curajul, acceptarea morții și încrederea în Dumnezeu

Une légende est une creation de l'ésprit humain [...] Dans les légendes, nous réalisons la justice, la beauté initiale, le sublime et notre grandeur humaine, que nous ne pouvons pas réaliser historiquement, à cause de tous ceux qui tyrannisent le monde. Dans les legendes et dans les mythes, nous réalisons notre faim du beau et notre soif de justice, en devenant ce que nous sommes réellement, c'est-à-dire des hommes admirables, les égaux de Dieu, comme nous l'étions aux premiers jours de la creation. Et parce que les armes, la force et l'iniquité ne peuvent rien contre les legendes, c'est dans les légendes que nous serons toujours des hommes admirables, faute de l'être dans l'Histoire. En écoutant les légendes, où l'homme est vrai et authentique, nous aurons toujours la force de supporter l'iniquité et de la combattre sur terre, jusqu'à ce qu'elle soit vaincue. La légende, vrai miroir de l'homme, lui permet de prendre conscience de sa sublime grandeur. ${ }^{30}$

Preocupat în special de statutul omului pe pământ, C. V. Gheorghiu pledează în operele sale pentru păstrarea singurei calități umane care i-a fost oferită de Dumnezeu din primele zile ale creației și care-l aseamănă totodată cu Dumnezeu, și anume, libertatea. Se regăsesc în opera sa, destul de des, pasaje care îndeamnă omul să lupte pentru a reveni la statutul oferit de Dumnezeu.

Motto-ul de la începutul romanului La condottiera, "C’est pour que nous restions libres que le Christ nous a libérés... $»^{31}$, este unul care încadrează romanul în rândul celor care promovează ideea că lumea există pentru și datorită omului, iar acesta trebuie să lupte pentru a-și păstra privilegiul, adică demnitatea și condiția divină.

30 Ibidem, p. 258: «O legendă este o creație a spiritului uman. [...] Prin legende noi îndeplinim dreptatea, frumusețea inițială, sublimul și măreția noastră umană, pe care noi nu o putem realiza din punct de vedere istoric, din cauza celor care tiranizează lumea. Prin legende și prin mituri, noi ne îndeplinim foamea de frumos și setea de dreptate, devenind ceea ce suntem în realitate, adică oameni admirabili, egalii lui Dumnezeu, aşa cum am fost în primele zile ale creației. Și pentru că armele, forța și nedreptatea nu pot face nimic împotriva legendelor, în acestea vom fi mereu oameni admirabili, cum nu am fost considerați în Istorie. Ascultând legendele, în care omul este real și autentic, noi vom avea întotdeauna puterea de a suporta nedreptatea și de a o combate pe pământ, până când va fi învinsă. Legenda este o adevărată oglindă a omului ce îi permite să ia cunoștință de sublima sa măreție» (traducerea noastră).

31 C. V. Gheorghiu, motto la romanul La condottiera, Paris, Plon, 1967: «Să rămânem liberi, aşa cum ne-a lăsat Dumnezeu» (traducerea noastră). 
Urmărind acțiunea romanelor prezentate de noi mai sus, C.V. Gheorghiu s-ar putea putea încadra, la o primă lectură, în rândul scriitorilor de romane polițiste, mai ales prin „schema” utilizată; sunt prezente crime, vinovatul apare doar la sfârșit, personajele implicate sunt polițiști, judecători, procurori, martori, un ocnaș etc. Însă pătrunzând mai adânc în substratul operei scriitorului, se observă că de fapt interesul său nu este de a descoperi vinovatul și pedepsirea acestuia, ci mai degrabă, de a scoate la suprafață problematica politică, morală socială sau religioasă, existentă în România, și mai ales în Moldova acelor vremuri.

Un roman care ne dezvăluie încă de la început semnificațiile religioase, prin titlul său, este, La condottiera, ce reprezintă o icoană a Maicii Domnului şi devenită protectoarea locuitorilor satului Acatist, situat în provincia Vrancea, Moldova. Numele satului în care se petrece acțiunea romanului amintit, Acatist, se încadrează și el în universul religiosului, acesta fiind numele unei rugăciuni

Le nom d'Acathiste est celui de plus bel hymne, de la plus belle prière de l'Église. Elle s'appelle Acathiste, car pendant qu'on la chante il faut reste debout. A-Cathiste, signifie, en grec, Non-Assis. ${ }^{32}$

După redarea semnificației reale a acestei rugăciuni, C.V. Gheorghiu ne transpune din nou în lumea legendelor, cea a Ne-Așezaților, renunțând pentru moment la cea a Nemuritorilor, prin negarea legăturii numelui acestora cu rugăciunea și susținând proveniența acestuia din activităţile și statutul oamenilor din acea perioadă. Locuitorii satului au însă aceeași viață, ca și cei numiți «nemuritori», ca toți moldovenii, una în care predomină asuprirea, sărăcia și nedreptatea pe care au trebuit să le suporte o perioadă îndelungată

Mais le nom du village de Vrancia n'a rien à faire avec l'hymne religieux. [...] Le village [...] s'appelle les Acathistes, les Non-Assis, les Toujours-Debout, car il est composé uniquement de gens sans terre, «des bras à louer» de journaliers. Ce sont des gens qui restent toute leur existence debout, prêts à s'engager et à suivre l'employeur. Non-Assis c'est la position propre aux pauvres. Aux serviteurs. Aux déshérités et aux prolétaires. Les pauvres restent toujours debout. Ce sont les riches qui sont assis. [...] Ils gagnaient leur pain comme valets de ferme, comme bras agricoles, comme ouvriers

32 C. V. Gheorghiu, La condottiera, Paris, Plon, 1967, p. 84-85: «Numele de Acatist reprezintă cel mai frumos imn, cea mai frumoasă rugăciune. Ea se numește Acatist, deoarece în timp ce se cântă se stă în picioare. A-Cathist înseamnă în greacă Ne-Așezat» (traducerea noastră). 
saisoniers. C'est à cause de leur condition de pauvres qu'on appelé donc les gens du village les Acathistes, les Non-Assis. ${ }^{33}$

Pentru a face și mai profund mesajul moral-religios al romanului, C. V. Gheorghiu, alege ca personaje principale un preot și un poet, persoane considerate de scriitor complementare

Je pense que le poète est le plus utile personnage de notre société. Sa mission est la vérité. Les prophètes des Juifs ont été des poètes et les poètes grecs ont été de prophètes. Les deux mots poète et prophéte sont presque synonymes. ${ }^{34}$

La Condottiera începe ca un roman polițist. Este o enigmă care ține cititorul în tensiune până la ultima pagină. Dar adevăratul subiect al romanului este condiția umană într-o republică populară. La 23 august 1964 - sărbătoare națională a Republicii Populare, morarul Nicolas Acathiste este asasinat în fața morii sale. $\mathrm{Cu}$ un cuțit plantat în spate, cadavrul său, încă cald, este descoperit de doi copii în mijlocul drumului. Imediat sosește poliția, iar în timpul cercetărilor de la fața locului, apare și fratele morarului, un călugăr. În afară de victimă, cei doi copii, o bătrână care nu poate umbla și călugăr, nu este nimeni în sat, căci toată populația era în satul vecin strânsă la defilarea obligatorie. Se consideră drept vinovat călugărul, acuzat că și-a ucis fratele. Pe parcursul anchetei ni se dezvăluie și viața celor doi frați rămași orfani de mamă de mici și crescuți doar de tată, cântăreț și slujitor al bisericii. Nicolas Acathiste - om al pământului și-a dorit de mic să devină morar. Prin căsătorie moștenește o moară, pe care o pune pe picioare cu ajutorul poetului Ovid Pantelimon, care îi dăruiește și o icoană, La condottiera, așezată de noul morar la poarta morii pentru a-i proteja atât familia cât și oamenii locului. Originară din Sicilia, dintr-o colonie de albanezi, care au declarat-o apărându-se în fața turcilor, ca fiind șeful lor, conducătoarea lor, icoana și-a făcut simțită prezența de conducătoare și

33 Ibidem, p. 85: «Dar numele satului nu are nici o legătură cu imnul religios. Satul se numește Acatiștii, Ne-Așezații, Întotdeauna-Sus, deoarece cuprinde doar oameni fără pământ, «brațe de închiriat», zilieri. Sunt oameni care rămân toată existența lor în picioare, pregătiți să se angajeze și să-l urmeze pe angajator. Ne-Așezat este poziția caracteristică săracilor. Servitorilor. Dezmoșteniților și proletarilor. Săracii rămân întotdeauna în picioare. Doar bogații se așează. [...] Ei își câștigă pâinea ca valeți de fermă, ca brațe agricole, ca muncitori sezonieri. Așadar, din cauza condiției lor de săraci, sunt numiți locuitorii satului Acatist, Ne-Așezații» (traducerea noastră).

34 C.V. Gheorghiu, într-un interviu ce prefațează romanul La condottierra, Paris, Plon, 1967, p. 17: «Eu cred că poetul este cel mai util pesonaj al societății noastre. Misiunea sa este adevărul. Profeții evreilor au fost poeți și poeții greci au fost profeți. Cele două cuvinte, poet și profet, sunt aproape sinonime» (traducerea noastră). 
protectoare a Ne-Așezaților încă din primele sale zile de poposire pe aceste meleaguri

A partir du jour où la Condottiera descendit chez les Acathistes de Vrancia, ceux-ci eurent du courage. Et cela c'était énorme, car le courage, le rêve et l'espoir sont comme les voiles pour un navire. ${ }^{35}$

Théophore Acathiste - preot și om al cerului, a dobândit această pasiune însoțindu-l pe tată său la înmormântări și pomeni pentru a se putea hrăni. Cei doi frați erau extrem de uniți «Le ciel du moine Théophore était mystérieusement mélangé avec la terre de Nicolas ${ }^{36}$, așadar departe de a-și face rău unul altuia. Crima este dezvăluită de poetul Ovid Pantelimon, care crezut ucis de oamenii Partidului Colaboratorilor, își face apariția la moară și cere protecție lui Nicolas, pe care îl ajutase și el la nevoie. Considerat de călugăr și soția morarului, singurul posibil ucigaș al lui Nicolas, dar a cărei existență nu o puteau divulga, deoarece erau ondamnați la moarte, cei doi păstrează secretul adăpostirii acestuia la moară, în ciuda gravelor acuzații aduse de oamenii legii. După crimă poetul fuge din ascunzătoare, ajunge la americani și le cere acestora să-i elibereze pe prietenii săi, acuzați pe nedrept. Cei doi sunt cumpărați de Comitetul liber, care mai salvaseră astfel și alți oameni, iar la întâlnire, pe aeroportul din Frankfurt, Ovid Pantelimon le mărturisește că de fapt, cel care l-a ucis pe morar este chiar șeful poliției, Zid Caracal.

Pentru C.V. Gheorghiu, această concepție deosebită despre lume, evidențiată mai ales în romanele analizate de noi, dar prezentă și în alte opere ale sale, se bazează pe o percepție moldoveană, extinsă însă la întreg poporul român. El dezvăluie această viziune asupra lumii, ca fiind o simbioză între vertical și orizontal. Omul este provenit din lumea verticală, însă fie că este locuitor al zonei de câmpie sau de munte, el a știut să-și regăsească întotdeauna dimensiunea sa verticală. Aceste două dimensiuni reprezintă pentru autor două moduri de viață, materialul corespunzător orizontalului și spiritualul verticalului. Omul complet, adevăratul român, este acela care nu își uită componenta verticală a originii sale. Însă pentru aceasta trebuie

35 C. V. Gheorghiu, La condottiera, Paris, Plon, 1967, p. 122: «Începând din ziua în care Condottiera a coborât la Acatiștii din Vrancea, aceștia avuseseră curaj. Și asta reprezenta enorm, căci curajul, visul și speranța sunt ca și pânzele pentru o navă » (traducerea noastră).

36 Ibidem, p. 123: «Cerul călugărului Théophore era misterios amestecat cu pământul lui Nicolas» (traducerea noastră). 
să păstrezi acea comuniune cu muntele, cu natura, printr-o viață simplă, de om sărac și ascetic.

Substratul tuturor acestor romane este evident ca fiind unul ce exprimă nostalgia unui exilat pentru provincia sa natală, a unui om care și-a alinat dorul de casă prin redarea frumoaselor legende despre patria sa, prin așezarea poporului său printre cele mai vrednice ale lumii, prin promovarea unor valori umane demne de admirat și de urmat. Ceea ce este interesant este faptul că nu a realizat acest lucru prin descrierea unei lumi opulente, a unei vieți perfecte, ci din contră prin opoziția dintre oamenii puternici și cei slabi, din care i-a scos învingători pe cei săraci material, dar bogați sufletește, demni, corecți, creștini, calități moștenite din strămoși, ce le-au asigurat dintotdeauna nemurirea.

\section{Bibliographie}

Băileșteanu F., 2005, Nihil Sine Deo sau Cruciada literară a ecumenistului Constantin Virgil Gheorghiu, Craiova, Editura Autograf, p. 147-148.

Gheorghiu C. V., 2003, Memorii. Martorul Orei 25, București, Editura Gramar, p. 23. Gheorghiu C.V., 2010, motto la romanul Casa de la Petrodava, București, Editura Sophia.

Gheorghiu C. V., 2008, Cum am vrut sa mă fac sfânt, Sibiu, Editura Deisis, p. 91.

Gheorghiu C. V., 1998, Nemuritorii de la Agapia, București, Editura Gramar.

Gheorghiu C. V., 1970, Le meurtre de Kyralessa, Paris, Editura Plon.

Gheorghiu C. V., 1967, La condottiera, Paris, Plon.

Gheorghiu C.V., 1955, Le peuple des immortels, Paris, Editura Plon.

Gillyboeuf T., 2010, Rapsodia română, prefață la romanul Casa de la Petrodava, București, Editura Sophia, p. 11. 